\title{
Civil Society Development and its Impact on the Democratization Process in Kosovo
}

\author{
Ardian Kastrati, MA (Phd Cand) \\ Department of Political Sciences, University of Prishtina \\ ardian.kastrati@uni-pr.edu
}

\author{
Doi:10.5901/mjss.2015.v6n2s5p69
}

\begin{abstract}
The process of establishing a sustainable and active civil society that effectively and responsibly participates within a democratic system of governance is crucial for transitional countries. After years of conflict and political uncertainty, Kosovo's independent status poses great challenges, including healing ethnic and political conflicts while rebuilding the nation's economy and infrastructure. The fragile society of Kosovo faces many challenges, the development of civil society is just one of them. Unfortunately Kosovo's civil society is not yet an effective and influential partner of government public decision-making. Civil society in Kosovo went through two developmental phases: the so called 'civil resistance' against Milosevic's regime in the 1990s, and the post-war period under international administration and building of democratic governance. In Independent Kosovo, problems of political and economic nature concerning the building of new institutions require the support of public discussion. The role of NGO's whose focus is political activism that tends to expand the practices of citizenship is reduced, and true public debate and coverage of all sides of important issues - elements crucial to a functioning democracy - are hampered if not prevented. Hence, the process of democratization of Kosovar society is negatively impacted. This article will explore the process of civil society development in Kosovo, from its days of origin, through the complicated political situations of the 1990s, and its increasingly active role in contributions toward the current democratization process.
\end{abstract}

Keywords: NGO sector development, EU integration, state-building, political activism, democratization

\section{Introduction}

During the 90s in Kosovo a number of civil society organizations were established. This was the beginning of the development of an early form of civil society. Albanian political parties founded in a later stage were direct continuation of these associations. With the disintegration of the former Yugoslavia, these political parties developed into a national Albanian movement. The so-called "civil resistance movement" organized parallel institutions of Kosovo as a public reaction to Serbia's isolation of Albanians from public life. The basic aim of Albanians was to fulfill their social needs of culture, education and common public life through civil society. The period under Serbian occupation led to the creation of a more or less active civil society.

After the war under the UNMIK administration the solidarity and voluntary engagement of the people of Kosovo for public causes has weakened. A huge number of small Non Governmental Organizations (NGOs) and local Media were formed solely for the purpose of soliciting grant money. As we shall see later in this study, Kosovar civil society was heavily impacted by the 1989 - 1999 repression of Serbian regime and the radical change of circumstances under UNMIK administration that followed the war in 1999. While Independent Kosovo is at the beginning of EU Integration process, progress towards acceptance into the EU involves annual progress reports that among other public aspects of society, assesses the status of civil society. Kosovo civil society and media has been continually assessed as weak. Now is the time for NGO representatives to establish more effective networking and integrative approach in order to play their important role for the democratization process in Kosovo.

On the other side despite the government's positive vision of civil society, there is a lack of institutionalized cooperation between the Government and civil society representatives. The government should help civil society in many aspects, and capacity building is one of them. The government needs to be more receptive of civil society criticisms and create circumstances that will allow civil society representatives to perform their role as watchdog with enthusiasm.

This study explores the process of civil society development in Kosovo, from its days of origin, through the complicated political situations of the 1990s, and its increasingly active role in contributions toward the current democratization process. My study begins with the discussion of the various meanings of civil society and various existing discourses of civil society and continues by describing the historical roots of civil society development in Kosovo before the war of 1999. The second part of the study includes the period under communist Yugoslavia and years of repression 
under Milosevic's regime and the process of establishing and developing NGO sector as part of civil society after the war, under the United Nations Mission in Kosovo (UNMIK) administration and in Independent Kosovo. The reason why NGO sector development will be in particular elaborated is that it represents the part of Kosovo's civil society that international agencies have mostly focused on through donor funding that particularly targeted NGOs. After the war in Kosovo the term NGO has become so popular and almost interchangeable with the term civil society. As a result, NGOs became very relevant for the political agendas of both international and national authorities. Finally in conclusions I try to compare and analyse the role of civil society before and after the war by indicating challenges that civil society, namely NGOs must overcome in order to meaningfully contribute to the current democratization process in Kosovo and the risks that they can pose when they decide not to become force for democracy.

\subsection{Civil Society from historical to contemporary perspectives}

\subsubsection{Origins and history of civil society}

There is no commonly agreed definition of civil society. Civil society elements are diverse and complex. Some of the literature considers whether it is this very fuzziness that explains the present popularity of civil society in that "it can be all things to all people" (Glasius, 2004,). However, it is important to clarify its historical roots before we see how the concept came to be understood in different contexts. Although it now relates to societies of different civilizations, civil society roots lie mainly in the West. Romans spoke for the first time of "societas civilis", a term introduced by Cicero. Socrates supported the idea that conflicts within society should be resolved through public debates, and Plato saw the ideal state as a society in which people dedicate themselves to the common good, while Aristotle saw the 'polis' as an 'association', that enabled citizens to share in the virtuous task of ruling and being ruled (O'Brien, 1999). Nevertheless, neither Greece nor Rome distinguished between state and society.

The medieval idea of differentiating between state and society was lost in the work of Hobbes, who in religion found only potential for conflicts. He wrote that if a society is to be held together at all, it must be through the power of the sovereign. But Locke, in 'Two Treatises of Government' (1963) provided a distinctively modern form of differentiation by combining the concept with that of voluntary association. Adam Ferguson developed the concept of civil society as a moral sphere in which human interactions can be protected from the state (O'Brien, 1999). On the other hand Tocqueville presented civil society as a network of non-political social organizations that strengthen democracy (Tocqueville 1969,). Hegel understood the distinction between market and state. In Hegel's analysis of society, the economy is a part of civil society, which is identified with market relations. Marx argued that civil society was strongly shaped by class antagonism and Rousseau thought that of the society where state should be absorbed into civil society. On the other hand Gramsci developed a concept of civil society that differentiated it both from the economy and the state, although he had a difficult time expressing the independent role of civil society without it being an instrument of state politics (Gramsci, 1971).

If we exclude the classical period, civil society meant every aspect of society that was not functionally and institutionally included within the State. The seventeenth and eighteenth century separation of state and society was a step of great significance. This later allowed theorists to conceive society as a social space in which the individual, alone or with others, could view the acts of society in order to oppose an oppressive state.

\subsection{Definition and concept of civil society: Theoretical and normative dimensions}

Many scholars think that because of its ambiguous nature the definition of the civil society concept sometimes is meaningless. Civil society belongs to a group of sociological and political theory concepts such as freedom, justice, equality and democracy that are also not clearly demarcated. At least two specific dimensions of the civil society concept are distinguishable: the theoretical and the normative role. In the context of theoretical role the concept of civil society analyzes dimensions of social life and social values, with citizens and civil organizations as key actors.

The normative role serves to motivate and mobilize citizens and other social actors for the establishment and development of various contents and forms of civil activities. The normative function is mostly manifested during periods of transition from less to more democratic societies. Both dimensions of the civil society concept have played significant roles, especially in countries where the position of civil society has traditionally played a marginal role.

Discussing the concept of civil society is quite fashionable today. Civil society is a popular term with politicians, academics and international agencies. We frequently hear politicians talk about the needs of the state and the market for a civil society. Civil society should provide an intermediate layer of governance between the citizens and the state that is capable of resolving problems without public coercion. (Edwards, 2004) The idea of civil society within the context of 
modern history offers perspectives on state-society relations. Within these perspectives, the state should be differentiated from civil society as a binding or organizing principal of political order. In this analysis, individuals and different organizations are part of the political order to the extent that they seek to participate in those processes. The concept of civil society has been defended in various ways by a variety of political and social theorists. Today's content of civil society does not result with a commonly accepted definition of the term, but focuses on whether the term should be a normative or non-normative tool of social science, and whether economic, religious and family relations should be considered as part of it. Walzer has defined civil society as the space of (politically) un-coerced human association and also the set of relational networks-formed for the sake of family, faith, interest and ideology. Civil society is also seen as a sphere of social interaction between economy and state (Cohen and Arato, 1992).

Most of definitions try to describe civil society as part of the society, but not directly part of the state, consisting of different organizations, which operate in the interest of the common good. One of the significant functional goals of civil society is to act as a force maintaining liberal freedom. This key function is a set of diverse non-governmental institutions, which are strong enough to counterbalance the state. Civil society is: 'a society in which polity and economy are distinct, where polity is instrumental but can and does check extremes of individual interest, but where the state is in turn checked by institutions with an economic base; it relies on economic growth which, by requiring cognitive growth, makes ideological monopoly impossible' (Gellner, 1994). While these are but a few of the formulations of civil society (some of them exclude familiar, religious, and economic realms) most of them share the most common definition of the term: the 'separateness of civil society and the state.'

\subsubsection{The idea of civil society: From normative to functional definition}

The core idea of civil society embodies an ethical ideal of the social order, one that harmonizes the conflicting demands of individual interests and social good (Seligman, 1995). In this context, its existence as independent from the state is a very important aspect. As we saw from the historical perspectives, the concept of civil society was defined differently by a range of German, French and Scottish Enlightenment figures, but common to all attempts was the articulation of the civil society's main problem: the relation between the private and public, the individual and social, and between individual desire and public concerns. In this context, civil society could be seen as autonomous sphere and independent from the state, but regulated by the state (Shills, 1991). This idea of civil society is not the focus of power balances between the state and civil society, but their inter-independence.

Civil society should be considered as the location of independent thought. As a result, a functional definition of civil society could replace the predominant normative definition: 'that civil society should not be defined negatively as opposition to the state, but positively, in the context of the ideas and practices through which cooperation and trust are established in social life' (Shills, 1991).

\subsubsection{Civil society and democracy}

Citizen participation in processes of public decision-making is an essential part of the democracy. Through its social and political activism, civil society gives voice to groups of citizens that don't feel represented in democracy. Civil society can be viewed as a solution to many challenges in contemporary democracies. Amongst other potentials, civil society organizations have expert knowledge in many areas of concern, and so are able to serve governments as counselors. (Habermas,1989). Participating in the system can be a good experience for citizens, allowing for a positive identification with their political system. This is how civil society can help strengthen some of the weaknesses in democracy and lower citizen dissatisfaction. This doesn't necessary mean that civil society organizations have identical interests and are always homogeneous. In essence there are many organizations within civil society that are undemocratic in their platform. Through the employment of disruptive, violent, illegal or socially irresponsible strategies, civil society organizations accustom their members to behavioral patterns, which are diametrically opposed to those necessary for the smooth functioning of democratic regimes. Non-democratic goals and strategies of some civil society organizations may generate openly non-democratic views and forms of conduct at worst (Forbrig, 2002). These aspects can directly threaten the maintenance of democratic regimes. It would therefore be misleading to conclude that all civil society organizations are interested in making democracy a reality.

\subsubsection{Democratic functions of civil society}

Civil society in the context of communist regimes had a different meaning compared to the meaning of civil society in the 
context of contemporary democracies. Because of the limited freedom of expression in communist regimes, civil society existed in someone's living room, in churches or in cafes (Brinton, 1990). Under the communist regimes independent civil society usually took on the form of small groups of citizen activism. Both representatives of independent and of the broad civil society contributed with different means and forms to overthrow communist regimes and follow transition toward democracy (Skovajska, 2008). As outlined above, at its best civil society can make a positive contribution to democracy, but at its worst may undermine democratic regimes. Some major functions through which civil society contributes to strengthening democracy are identified as: 'The Lockean Function (Control of State Power), The Hegelian Function (Interest Mediation), The Pluralist Function (Social Integration), The Non-Profit Function (Service Provision) and The Tocquevillean Function (Political Socialization) (Forbrig, 2002).

Although it is possible to identify some major functions through which civil society contributes to strengthening democracy, this doesn't necessarily mean that we do have a precise definition agreed from all authors for the concept of civil society. Many authors give different meanings to the notion of civil society. Not everyone means the same thing when they discuss it. Consequently, it is difficult to formulate a precise research question which contains a concept which itself is not precise.

In general, civil society is seen more as a multifaceted concept, although it is noticeable that the differentiation between the state and civil society is mostly discussed. Within this context, my research remains within the concept that defines civil society as autonomous sphere and independent from the state, but regulated by a legal framework from the state. This is the concept of civil society that is not defined negatively as opposition to the state, but positively, in the context of the ideas and practices through which cooperation and trust is established between the state institutions and civil society thus contributing to the democratization processes.

Having in consideration that the relationship between civil society and Kosovo institutions went through two very different stages of development, the general research question that guides my study is: What are the differences between the roles and contributions of civil society in Kosovo before and after the war of 1998-1999? In order to answer to my research question I will focus in two different circumstances, the pre war situation under the Milosevic's regime and the post-war period under international administration and building of democratic governance.

\section{Civil Society in Balkans: In Transition from Communism to Post Communism}

Active civil society fosters democracy in a number of ways: by dispersing power and thereby keeping a check on the state and by developing social capital. Very few countries, if any, that had no tradition of developing civil society during the communist period, emerged with a strong civil society after the communist period (Miszlevitz, 1999). Any countries that had a relatively well-developed tradition of civil society before (or during) communism ended with weak civil societies by the end of communist rule. 'Their competitive advantage was, however, to have the blueprints of civil society still present in their institutional memory, this was a legacy on which they could base their efforts to reconstruct their democracies.' (Hann, 1992).

Civil society in post communist Europe is poorly developed. Because of the underdeveloped civil society in Eastern Europe and South Eastern Europe some authors refer to this as 'illusory civil society'. This is because the number of individual participants in civil society is low compared to the impressive number of NGOs. Another concern about these organizations is that most are one man shows, with little political or social influence (Whitehead, 2004). Politicization of civil society leaders in post communist countries is also evident, as some move into high political or the state administrative sphere after a very short period working with the civil society.

In order to achieve a better understanding of the complexities of civil society in post communist countries, it is important to address some of the key relationships between civil society and the state, which affects the democratization process in these countries. As discussed earlier, the relationship between the state and civil society is the subject of among different authors, philosophers, scholars and academicians, beginning from the Enlightenment period until modern times. While overthrowing communist regimes leading South-East European dissidents have chosen the 'anti-system' model because of the communist dictatorships (Mudde, 2003). However, while leading civil society organizations against communist regimes, some dissidents became state leaders in the transition (Vaclav Havel, Lech Walesa), some authors believed that this is the ultimate victory for democracy, while others argue that unification of civil society and the state in post-communist countries is the structural destruction of civil society. Because of the 'anti-system' model and approach during communist rule, civil society was believed to be 'anti-state \& anti-institutional' irrespectively of the state of regime. This remained the belief following the fall of communism (Mudde, 2003).

The idea of civil society groups as state resistance and alternatives to political parties finds its best expression in many post-communist European countries, whereas in Western Europe civil society is a sphere of social autonomy or 
voluntary cultural and social organizations. Although civil society organizations led the opposition to communist states they should not necessarily be seen as adversaries of the state. To some degree it is possible for civil society to join state efforts in establishing and consolidating new democracies. Therefore, it is possible to elaborate the current perspectives of civil society development in post-communist countries, only by searching for the origins and effects of civil initiatives before and after the fall of communism.

Eastern and Southeastern European countries shared certain features, including party-state control over the most important institutions and other sectors of public life: supervision over organized social activities, widespread police control, suppression of independent activities outside of state control (including the private economic sector) and the outlawing of any activities deemed challenging to the ruling party. However, not in all of these countries the situation was the same if we compare state control over civil society. Best illustration for this is 'Solidarity', a social movement during the 1980s' in Poland that was using the methods of civil resistance to advance the causes of workers. After nine years of existence they finally managed to outmaneuver the communist leadership. There were growing and very well organized dissident groups in Czechoslovakia and East Germany, while Hungary had a substantially developed private sector. Social activism organized around these movements produced alternative or independent cultural elites.

On the other side, since the fall of communism in the 90 s, the Western Balkans had been undergoing fundamental and multiple transformations. At the early phases of the transition there are numerous constraints on the development of civil societies in Western Balkans, such as: the legacies of communism, impact of nationalism, and the manipulation of ethnic politics. It is obvious that the question of nationalism and ethnicity impacted negatively on the development of a civic-based democracy in the Balkan region. Kosovo is no exception here.

\subsection{Legacies of communism and nationalism}

The legacies of communist rule on civil society have proven to be negative. In most of the South East European countries, communism reinforced collectivist models of individual and social obligations to the state rather than individual liberties. With little tradition of mediation and resolving group conflicts, including religious and ethnic conflicts, it missed an essential process for the development of a fully functional and active civil society. Civil society elements during communism and the post-communist transitional period were the embodiments of this culture. On the other hand, the negative nationalism that characterized the Balkans during the 1990s promoted authoritarianism, which fostered an intolerant political culture, and justified government controls over the mass media and other public and private institutions with the pretext of defending endangered national interests. The road to an active and diversified civil society can be especially long and arduous where the legacies of communism are reinforced by the deliberate manipulation of nationalism.

Kosovo illustrates well the important role that nationalism and myths play in shaping human behavior. Manifestations for a myth known as Kosovo battle fought in 1389, marked the beginning of the collapse of ex-Yugoslavia. With the fall of the most of the communist regimes in Central and South Eastern Europe the concept of civil society discourse entered Kosovo in the beginning of the 1990's. This concept was not seeking one objective as most of South Eastern European countries did (to turn down communism and start the democratization process) but to start the state building process in conjunction with democratization and transition process (if possible at all in those circumstances). Civil society activism in Kosovo began as a reaction to Milosevic's regime and his hegemonic program inspired by a nationalistic myth. Before we examine forms of civil resistance against Milosevic's regime and how Albanians used civic activism as a form of national emancipation in 1990s, it is worth considering civil society in Yugoslavia with Kosovo as a part of it.

\subsubsection{Yugoslav Civil Society from socialism to pluralism}

The disintegration of Yugoslavia actually started with the abrogation of autonomy of Kosovo. The first civil initiatives in Kosovo took place after 1989. The institutional vacuum created in 1989-1990 after a very rapid disintegration of the Kosovo communist party and abrogation of autonomy created space for new initiatives, particularly from new generations struggling for more pluralism. But under Milosevic's repression, pluralism was impossible. Starting from 1991-1992 Albanians were interested in lobbying for independence. During the socialist Yugoslav rule civil society discussions in terms of their spectrum and intensity were fewer and weaker in Kosovo compared to other Yugoslav Republics. In the other republics: Serbia, Bosnia and Herzegovina, Croatia, Montenegro and Macedonia debates for civil society were predominantly theoretical and lacked energy of the new social movements. Slovenia brought fresh civil and democratic ideas such as the de-politisation of public sphere and introduction of multiparty pluralism, which were rejected by strong 
republics like Serbia. Slovenia was left with no other political alternative than the Yugoslav one, and this is how, both theoretically and practically, they continued to use the concept of civil society as a form of national emancipation.

By the end of the 1980s, other Yugoslav republics had designed their national programs. These were nationalist programs without civil society, whereas the Slovenian program included 'nationalism plus civil society'. In Serbia and Croatia, it appeared that the only alternative to communism was nationalism. 'There were, however, efforts in most Yugoslav republics to develop a non-nationalistic, democratic and pluralist system. One of them is the formation of the Association for a Yugoslav Democratic (UJDI) initiative, which aspired to be equivalent to East German New Forum.' (Ingrao,2009). In Kosovo the UJDI failed to attract members of different nationalities, thus obtaining the membership of only few Serbs and hundreds of Albanians.

Another influential center for Albanians in 1980s was the Writers Association, which throughout Yugoslavia supported intellectual freedom (Clark, 2000). The Kosovo Writers Association defended alleged 'Albanian separatists' who were facing prison from the system. In the years to come the president of the Association, Ibrahim Rugova, became one of the main voices of Kosovo for the international and domestic press as a head of the political movement: the Democratic League of Kosovo (LDK), which was founded in December 1989 (Clark, 2000).

\section{Civil Society in Kosovo before the War of $1998-1999$}

\subsection{Kosovo civil resistance movement in 1990's}

During 1990 LDK together with other civil society organizations established a united front against Serbia's regime by providing guidance for the civil and peaceful resistance against the regime in Belgrade. In many observations of Western journalists and politicians at the beginning of 1990s criteria for 'civil society' in Kosovo was never agreed (Kipred, 2005). For some of them LDK was identified as a civil society organization; for others who recognized LDKs political character and activism as a national political movement.

Between 1989-1990 civil society gained further substance with the foundation of a variety of other civil non-state organizations and political parties, such as the Social Democratic Party, Youth Parliament of Kosovo, and Green Party. All of them together were identified as "Kosova alternative" (Clark, 2000). In the same period came the formation of different independent organizations, such as the Council for the Defense of Human Rights and Freedoms (CDHRF) (1989) and the Union of Independent Trade Unions (UITU) (1990).

Apart from non-violence protests solidarity among Kosovo Albanians was a very important element of the national and civil resistance in the 1990s. In this context, the Albanian movement directed its attention to the violence within their community: the blood feud. The most common customary law among the Albanians was the The Code of Leke Dukagjini (from here "The Code"). "The Code" included an elaborate legal rule that tried to regulate the blood feud. The initiative for reconciliation of blood feuds amongst Albanians became a widespread social movement that promoted a very positive social change in the society. Other forms of civil resistance were developed in the beginning of 1990s (Ingrao, 2009). 'Thousands of people would put candles in their windows or balconies, which marked the beginning of the curfew, a symbolic expression that despite the state of emergency Kosovo Albanians still held the key to the situation. At the beginning of 1991 an hour long silent demonstration took place in Prishtina, with the posters declaring 'Stop the violence'. " (Clark, 2000).

The intuitive non-violence movement taken up by Kosovo Albanians from 1989-1992 and absorbed into their identity and culture was a durable foundation for civil resistance. Not just civil resistance, but solidarity among the population, was one of the overarching principles. The 'Mother Teresa Association' was another very important NGO, becoming the backbone of the Kosovo Albanian parallel healthcare system after thousands of Albanian personnel were dismissed from their positions in public hospitals. "Mother Theresa' provided medical services and distributed food all over Kosovo to all categories of the civil Albanian population. The organization was funded by private donations from inside Kosovo, and later out of solidarity contribution of 3 percent of wages by the Albanian Diaspora (Khdr, 2008). This money was collected from financial councils that were established by LDK in the early 1990s. It is important to note that 'Mother Teresa' conducted a no-cash policy because of the risk from raids by the Serbian police (Clark, 2000). On the other side, all state media in Kosovo in the 1990s was at the service of policies of Milosevic's repression and genocide. "Under these circumstances, during 1990-93, a "parallel society" in Kosovo developed with the efforts of Albanian professionals, teachers, and activists to maintain the functioning of society, and to exhibit a political will, which used the ensuing institutional basis to claim statehood for Kosovo' (Kipred, 2005). This repressive situation pushed the Albanian community to look for other alternatives.

As a form of their civil resistance to Serbia, Albanians created their own system of education out of the public 
facilities. 'Self-financed post-autonomy graduates in Kosovo were the generations of the Kosovo Republic. They no longer studied the people's heroes who had fought for 'brotherhood and unity' of Yugoslav nations and nationalities' (Schwandner -Sievers and Jurgen Fischer, 2002). Education was organized in private houses and garages, especially for high schools and University of Prishtina (UP). New curricula were enacted with an aim to promote the Albanian national identity. 'This came to be known as parallel education. It was the cause that galvanized the entire Albanian community in Kosovo into action, triggering its unprecedented homogenization. Albanian parallel education in Kosovo emerged as an embodiment of the Albanian civil and peaceful resistance, and an argument used to prove the existence of the Albanian independent state in Kosovo' (Kostovicova, 2005). Parallel institutions became a point of national pride and motivation for further solidification among Albanians for their statehood. The launch of the parallel system was also a gesture by Albanians to show to the international community 'the independent Kosovo'.

LDK leadership used this model of success as an important symbol and proof of Albanian statehood in Kosovo. One Albanian analyst suggested that Ibrahim Rugova should more accurately be called "President of the parallel schools of Kosovo" than 'The President of Republic of Kosovo', his official title. Civil society in Kosovo emerged and took its form within the context of non-violent civil resistance led from LDK and Mr.Rugova. 'The non-violence movement became part of the modern Albanian identity that drew together both village patriarchs and urban intelligentsia in a common effort to avoid a tragedy' (Clark, 2000). While in much of the communist bloc, peaceful transition from totalitarian and one-party rule to plural and democratic regimes, buttressed by civil society contributions, was made possible, Kosovo's civil society experienced a different kind of development (Khdr, 2008). The distinction between civil and political society was blurred. The reason was very close cooperation and sometimes the uniform actions between political parties and civil society that were imposed from the deteriorating political and economic conditions in Kosovo. One can say that pre-war civil society organizations were strongly politicized and nationally oriented as they embodied the goals of the Albanian Kosovar nationalist struggle by means of peaceful resistance under the civil society umbrella (Sterland, 2006).

\subsubsection{Kosovo Civil Society after the war of 1998- 1999}

After the withdrawal of Serbian forces in 1999 the political circumstances in Kosovo changed radically. Kosovo entered a unique historical period to be followed by controversies with UNMIK, protection of minority rights and its status issue. Kosovo turned into experiment for different formulas of peace building and reconciliation. After the war of 1999 the majority of international donors and agencies interested in civil society development have focused their funds mostly on NGO sector. NGO sector role was so relevant to UNMIK political agenda after the war, but not less important to Kosovo institutions and political parties of Kosovo after UNMIK became irrelevant. Under UN administration and protection by NATO troops, Kosovo society was impacted by the mass arrival of international non-governmental organizations (INGOs), most of them with the objective to provide humanitarian aid, reconstruction and reconciliation. The INGO 'boom' in the aftermath of the conflict impacted the massive expansion of the local NGO sector.

Radical socio-political change in post war Kosovo is not the only reason for the quick development and new strength of the NGO sector. The legacy of the 1990s also explains that despite operations under Serbian repression and pressures to maintain one singular course within the national civil resistance, independent organizations experienced some kind of pluralism during the 1990's. Therefore, pluralism was not totally inexperienced, or better to say, unknown (Clark, 2000). As a result, at least some of the independent organizations that existed before the war in 1999 onwards had to go through slight reconfiguration and continue to expand within a new context. While civil society in the 1990s was associated with civil resistance, after 1999 under the new circumstances of constructing a new political system, civil society underwent a necessary transformation. This process of transformation was rapid as it shifted radically the focus of civil society organizations from the politics of resistance to the politics of reconstruction and peace building (Kipred, 2005).

Compared to pre-war circumstances, NGO sector after the war experienced a UN-sponsored language of peace building, reconstruction, reconciliation and multi-ethnicity. In order to please UNMIK and lots of international donors all types of associations and NGO's mentioned above were chasing donors whose funds they embezzled by organizing largely meaningless trainings, conferences, and roundtables on how to reconcile Serbs and Albanians just couple of months and years after bloody war was finished (Khdr, 2008). Most of the NGO's will become politically relevant only when UNMIK and other international donors needed them to implement similar short-term projects. Consequently the rise of thousands of local NGOs was accompanied by a feeling of public skepticism and a fear that they are not driven by authentic needs but apply for similar projects to please foreign donors.

In 2002, after the new Kosovo institutions were established the relationship between these NGOs and state institutions needed further reconfiguration. At this point NGOs formed after the war removed from UNMIK structures and 
no longer had any direct influence in policymaking. This phase of development of NGO sector as part of civil society has proven to be quite challenging, especially for that part of NGOs that emerged after the war (Brand, 2003). On the other hand, several major associations that existed before the war registered as NGOs. These organizations together with others that have succeeded from the disbanded Kosovo Liberation Army (KLA) were connected to major political parties and had better access to the government resources when their respective parties would come in power.

Another serious problem that started between the years 2003 and 2004 was the decrease of international donations. This started to affect the financial sustainability of most NGOs. At this point from 2003 to 2005, not only as a result of the proliferation of NGOs but also because of the antagonistic relationships between major NGOs, the Civil Society of Kosovo gradually began to lose its pre war homogeneity.

The antagonistic relationships within the NGO sector were mostly a consequence of a variety of historical reasons and competition born out of competition for foreign and domestic funding. After the formation of Kosovar institutions, powerful NGOs started to take political sides and represented interests based on organizational histories and inter-NGO linkages, rather than based on the forms of their activities (Atrc, 2008). Consequently, NGO sector became divided between different types of groups, from large-scale network organizations that have pre-dated the war to NGOs that emerged after the war (Kipred, 2005). As a result of this division a good number of NGOs failed to build their own identity as part of civil society, instead they formed particular 'cliques' within Kosovar institutions and political parties, or within the international community in Kosovo. Such cliques are usually connected to major sources of donor money like the international organizations coming both from U.S. and EU and later to the Kosovo Government and sometimes with political parties (Kipred, 2005). This antagonism impacted fair competition, because animosities and intolerance usually stretched into a highly personal level, thus preventing NGO networks from having a more unified voice towards the Government.

Similar animosities reflected the important interaction of some NGOs with the Kosovo institutions, as cooperation would often be sporadic and too dependent on individuals. The government(s) felt quite comfortable, as this fragmentation existed and as long as Kosovar media gave only limited space for NGOs to organize true public debate and coverage of all sides of important issues. Consequently, the political system these days remains partly open for cooperation with NGO sector and their input in the policy process and political influence is greatly constrained.

\section{Summary and Conclusions: Looking Forward}

\subsection{Birth or Rebirth of Kosovo's Civil Society}

During the breakdowns of the communist regimes there is no doubt that civil society played an important and historic role. Civil society's contribution was also significant in the process of democratic consolidation that followed the breakdown of the communism in East Central European countries. The East Central European movements of 1989 sent reverberations throughout the continent, including the former Yugoslavia, and by default in Kosovo (The Independent International Commission on Kosovo, 2000). As outlined earlier civil society in Kosovo went through two developmental phases: civil resistance and solidarity before the war of 1998/1999, and the post-war period and building of democratic governance after the war. Consequently, these days NGO sector in some of its nuances is still divided among NGO's that pre dated 1999 and those that were formed after the 1999. Relationship between these two groups of NGOs is still antagonized.

In a given setting in order overcome these antagonisms, become a force for democracy and be able to contribute to the democratization process by deliberating public problems, most of the NGOs should first start to address their internal problems such is the legal framework, prepare a strategy to strengthen their participation in the European integration process, reach out to their target groups, address their financial sustainability problems and improve cooperation with the Government. NGO's should be persistent on drafting legislation that will better facilitate their activities in the future.

NGOs are among the most important actors in the complex constellation of stakeholders in the EU Integration process. As the integration process develops in the future, Western Balkan countries will continue working to secure and/or improve present positions with regard to their European agendas. This ultimate goal continues to be challenging and it will call for an action from multiple society layers, whereas NGOs as an important part of civil society can contribute to the quality of and public support for pre-accession related reforms. NGOs could play an indispensable role in sustaining democratic development and good governance, especially against the background of historical complexities and challenges of transition in Kosovo. NGO sector can become one of the main partners in Kosovo's EU integration process, but their capacities for participating in policy- and decision-making need to be improved (Progress Report, 2008). The leadership of both Kosovo institutions and NGO sector in cooperation with international actors involved in 
Kosovo should prepare a strategy in order to strengthen the role and participation of NGOs in the European integration process.

There are several instruments that NGOs can use to participate in the process. Kosovo needs to develop a sustainable triangle between the government, the EU and civil society relations. NGOs need also to reach out more often to their target groups in order to create stronger networks between them. It is important to shun the individualistic and narrow interests when it comes to networking, and see the benefits of NGO joint action, which is ultimately a more powerful force compared to their individual capacities. They need to reach out more to their target groups and apply a more focused approach in their mission, rather than opportunistically shifting towards donor priorities.

Another serious problem that remains to be addressed from NGOs is that of financial sustainability. NGOs should not depend solely on international donors. Government funding, private donations and other funding options would help to ensure institutional and financial sustainability. Last but not least cooperation between the Government and NGO sector should be based on acceptance of shared responsibilities for relevant matters, recognition of shared values, and in sharing financial and human resources. In order to do this not just NGO's but government institutions should also reconsider being the exclusive provider of public services and identify activities the NGO sector could perform. NGOs should work to build their capacity and professionalism and duly inform the public about their activities, as well as improve cooperation between NGOs. The Kosovar government should also be aware that it cannot address all the needs of a transforming society alone, which is why they need NGO efforts to complement them. This could possibly reduce current antagonism within the NGO sector that does enormous harm to the political efficacy of the civil society by taking different forms in practice.

At the time of democratic transitions in South Eastern Europe, different models existed in the West regarding the cooperation between the civil society and the state. Those are mostly models of a close relationship and cooperation between civil society and the state institutions, both in Western European countries and in United States. Leading dissidents and other groups in South Eastern Europe, including Balkans, have chosen the model of complete 'opposition' or 'anti-institutional' behavior. This model was not supported only because of the particular context of the dictatorship regimes, but because civil society was believed to be inherently 'anti- institutional' irrespective of the nature of the regime. While in South East European countries this behavior marked the period after the fall of communism, in Kosovo similar relationship between NGO's and state institutions took place after 1999 (Atrc, 2008). It means that some NGO's even after 1999 in many situations continued to practice that same aggressive negativity towards the Kosovo state institutions as they did during the 1990s under the circumstances of apartheid against the Serbian regime. It is understandable that this frustration comes as a result of highly centralized political party structures in the Government(s) which supports only particular NGOs and prevents other NGOs from having greater access to the policy making process, but this could also be a justification only for a number of NGOs that do not have well formulated policy goals so they could contribute to the policymaking process.

Regardless of this situation many of these NGOs are needed for the democratization process, especially NGOs with strong constituencies and those interested in impacting state policies. However, some of these NGOs need to change their approach and this would mean not only to offer alternatives for the problems they identify, but look for ways to actively participate in the policymaking process.

What remains ahead for NGO sector as a very important part of civil society is try to articulate a new vision for Kosovo's future (Kipred, 2005). This would be possible also with a more integrative approach from the political parties, and by drafting legislation that will enable NGOs to participate in the decision making process, using EU mechanisms and instruments to contribute to the democratization processes and by improving communication between media and NGO sector. NGOs should be more independent from state but more active on behalf of citizens towards the state. 'This doesn't mean that they should take the role of the state or of other actors in the society, but they should improve the interplay of citizens with the state and achieve better effectiveness and responsiveness of its institutions.' (Spurk,2008). In order to establish a collective identity within Kosovo's new polity, NGOs, apart from sensitive historical elements and meaningful civic ideologies, need to articulate the civic engagement and activism. While articulating the overall values of active citizenship, political engagement, plurality and solidarity, NGO sector will complement the so-called 'bigger picture' by becoming a central factor for the development of a sustainable democratic community.

It is also important to define their agendas and build constituencies. Thus, a better cooperation between the Government and NGOs could be established. First step towards a meaningful cooperation between the government and NGO sector is to define the rights and responsibilities through a legal framework, which would formalize the cooperation between each of the sectors. It is the duty of the Government to create a favorable climate in order for NGOs to become more functional. Because the Government is dominated by rigid party structures it is not expected that they will be the first ones to start this reform. If communication between Government and civil society representatives brings no results, 
NGO representatives could use EU Integration as a process in order to address this concern within the European Partnership instrument. The EC has a huge bargaining power within the EU Integration process, and they address issues regularly with national authorities, and follow up whether the government has implemented their recommendations and report accordingly in the progress report.

As outlined earlier various authors conceptualized the relation between civil society and the state in different ways. 'Historical examples of this interpretation include Locke's thesis that civil society offers protection from the potential abuses of state power. Similarly, Montesquieu argued for a balance between state and civil society. Likewise, deTocqueville advocated self-government and civic participation as a means for counteracting power abuses by the state and/or other social majorities.' (Fischer 2006). Civic performance in its essence implies good behavior of a citizen and his or her acting for a "good cause" that is in favor of the interests of the entire community. The civic performance does not necessarily imply "anti-state", "anti-social-order" or anti-institutional actions, although, most frequently, it may seem to belong to the "anti" type of behavior. It seems that under new circumstances NGO sector is having problems to understand its new role. Their role as part of civil society is not to change the system (this was pre 1999 goal), they should be contributing to the development of the system regardless of the fact that this might sound complex if we take into consideration constants clashes between major NGO groups with the Government.

NGOs interested in impacting state policies should look for the instruments and mechanisms that will help reshape and improve their cooperation with the Government structures. In order for this to happen a contribution from both NGO sector and of the state is needed. Only when this happens will the new generations of Kosovo NGOs see the state as their protector, and political leaders will see civil society representatives as their supporters rather then a threat to themselves, only then, will a truly vibrant civil society be able to develop in Kosovo. However, this is not an easy mission. It is important to be recognized that participation of more citizen groups and civil society organizations in governance could potentially produce conflicts of interests between them. This is likely to happen in transitional societies like Kosovo. To avoid similar situations state institutions should enforce consistently legal and judiciary system reforms in order to settle disputes between all possible parties involved in the future public decision-making.

The Republic of Kosovo, in its seventh year as an independent state, faced significant challenges in addressing international and domestic events. Kosovo made global headlines when the International Court of Justice declared that Kosovo's unilateral declaration of independence did not violate international law. The country's image in the international arena was seriously tarnished when a member of the Parliamentary Assembly of the Council of Europe, Dick Marty, came out with a report on alleged criminal activities of the Kosovo Liberation Army during and after the war. The dialogue between Kosovo and Serbia may improve regional stability and cooperation, but as EU does not have a unified position on Kosovo independence, it may face similar problems also when its concerns the dialogue. In the meantime, the Kosovo Government will continue to struggle for a stable coalition, and their main challenge will be to rally the political potential in order to fight organized crime and corruption. There is a question whether they will manage to implement fully their executive mandate, specifically in the northern municipalities, in order to build a state with a functional rule of law.

These circumstances are the opportunity for NGO sector as part of civil society to play a role in determining the parameters and the quality of governance and social policy during the process of peace \& state building. As it can be seen, civil society groups were a factor under the circumstances of apartheid and can be potentially a force for peace and democratization process. 'Civil society actors can strive for democratic values and reconciliation. But in many countries undergoing transitions from violence to peace, civil society per se does not necessarily contain an emancipatory potential. This is further undermined when the civil society itself must be democratized.' (Fischer,2006). In today's world 'Civil Society' has become a widely used term, essentially it is "the big idea on everyone's lips" (Edwards 2004). Instead of aiming the job 'everyone wishes to perform', Kosovo's NGO sector as important part of civil society should go through the process of internal democratization before its serious engagement in the very important processes of state building and EU integration. This could be the so-called process of 'rebirth' of the civil society in Kosovo.

Democracy is a process and it will take some time for Kosovo NGO's to develop their political activism. Citizens in democracy have both rights and duties and this is the fundament for the democratic governance as they are given the opportunity to actively shape their individual interests within the public sphere. To understand socio-political changes in the 'New-Born' Kosovo, civil society needs to be taken into account in order to give answers to many ethical questions regarding the political and institutional practices in independent Kosovo. Effective civil society requires effective state institutions. Government structures will have to allow greater presence of NGOs in policy-making process.

The above initiatives followed with an action plan from all sides are relevant to foster and enable a better environment for the NGO sector development, which could in a later stage produce a healthier STATE-NGO relationship. With similar actions taken from all possible stakeholders NGO's could potentially overcome the current fragmentation and antagonisms. This would be a new atmosphere with no need for the so-called 'anti institutional' model of behavior for 
many NGOs, because there will be less space for the Government to play favoritisms among different NGOs and associations, and because fair and open competition will be guaranteed by law. Operating in such circumstances many NGO representatives would gradually realize that civil society's pre 1990 role was different from todays. Today, their roles and contributions are different as they can seriously contribute to develop the system, not necessarily by using the 'antisystem' approach. It is civil society's role to make state institutions more accountable and effective in order to strengthen citizen's respect for the state and encourage their positive engagement. The fact the civil society is independent doesn't mean that it should be in tension with the state institutions and permanently criticize and oppose them.

This is a fantasy of a creative, fluid and free civil society. This is the concept of civil society that is not defined negatively as opposition to the state, but positively, in the context of the ideas and practices through which cooperation and trust is established between the state institutions and civil society thus contributing to the democratization processes and potentially becoming a 'postmodern' panacea for the Kosovo society.

\section{References}

ATRC (2008): NGO Sector in Kosovo: development, challenges and opportunities, Prishtine

Brand, Marcus (2003): The development of Kosovo Institutions and the transition of authority from UNMIK to local self-government, Centre for Applied studies in International Negotiations, Geneva.

Brinton, Aspen: The Idea of Civil Society. [Online] Available :http://users.ox.ac.uk/ oaces/conference/papers/Aspen_Brinton.pdf (July, $18,2014)$

Clark, Howard (2000): Civil Resistance in Kosovo, Pluto Press, London

Cohen, Jean. and Arato, Andrew. (1992): Civil Society and Political Theory: MIT press. Cambridge

Edwards, Michael (2004): Civil Society: Polity Press, Cambridge.

Fischer, Martina (2006): Civil Society in Conflict Transformation: Ambivalence, Potentials and Challenges, Research Center for Constructive Conflict Management)

Forbrig, Joerg (2002): The Neexus Between Civil Society and Democracy, Reichel Walter, p-79-103

Gellner, Ernest. (1994): Conditions of Liberty: Civil Society and its Rivals, Penguin Books, London and New York.

Glasius, Marlies (2004): Civil Society, [Online] Available: www.fathom.com (September, 10, 2014)

Gramsci, Antonio (1971): Selections from the Prison Notebooks, International Publishers, New York.

Habermas, Jurgen (1989): The structural transformation of the public sphere, Trans.T.Burger.MA, MIT Press, Cambridge

Hann, Chris (1992): Civil Society at the Grassroots: A Reactionary View in Democracy and Civil Society in Eastern Europe, ed. P.G. Lewis, St. Martin's Press, 152-165, London

Ingrao, Charles and Emmert Thomass (2009): Confronting the Yugoslav controversies, a scholars Initiative, Purdue University Press, West Lafayette, Indiana

KHDR (2008): Kosovo Human Development Report, Civil society and Development, Prishtina, p 45-47, 90-92, 119-123

KIPRED (2005): A changing civil society-Kosovo's NGO Sector after the War, Prishtina, p 5-7, 10-11, 23-24

Kostovicova, Denisa (2005): The Politics of Identity and Space Routledge, New York

Locke, John (1963): Two Treatises of Government, Cambridge University Press, New York

Miszlevitz, Ferenc (1999): Illusions and Realities: The Metamorphosis of Civil Society in a New European Space, Szombatheley: Savaria University Press

Mudde, Cas (2003): Developments in Central and East European politics 4, chapter 13. p-213

O'Brien, Rory (1999): Philosophical History of the Idea of Civil Society, 1-2

Progress Report for Kosovo (2008): European Commission, Brussels

Schwandner -Sievers Stephanie and Jurgen Fischer, Bernd (2002): Albanian Identities-Myth and History, Indiana University Press, Bloomington

Seligman, Adam (1992): The idea of Civil Society, Princeton University Press, Princeton, New Jersey

Shils, Edward (1991): The virtue of Civil Society, Government and Oppositions, 3-20.

Skovajsa, Marek: Independent and broad Civil Society in East-Central European Democratizations, Taiwan Journal of Democracy, volume 4, nr. 2, 47-73

Spurk, Christoph (2010): Understanding Civil Society, contribution to book Civil Society \& Peace-Building, Lynne Rienner Publishers, Boulder \& Co, USA, p-3, p-5

Sterland, Bill, (2006): Civil Society Capacity Building in Post-Conflict Societies: The Experience of Bosnia and Herzegovina and Kosovo, International NGO Training and Research Centre, Oxford

The Independent International Commission on Kosovo, (2000): The Kosovo Re port: Conflict, International Response, Lessons Learned, Oxford University Press, Oxford

Tocqueville, Alexis (1969): Democracy in America, 2 Vols, Garden City, NY: Doubleday 516

Walzer, Michael. (1990): The Idea of Civil Society, Dissent, New York 